\title{
A Continuous Electronic Nose Odor Monitoring System in the City of Agadir Morocco
}

\author{
Ahmed Chirmata ${ }^{*}$, Ihya Ait Ichou ${ }^{1}$, Thierry Page ${ }^{2}$ \\ ${ }^{1}$ AQUAMAR Laboratory, Photocatalysis and Environment Team, Department of Chemistry, Faculty of Sciences, \\ University Ibn Zohr, Agadir, Morocco \\ ${ }^{2}$ Odotech Inc., Montreal, Canada \\ Email: ${ }^{*}$ chirmata@yahoo.fr
}

Received 18 December 2014; accepted 1 January 2015; published 14 January 2015

Copyright (C) 2015 by authors and Scientific Research Publishing Inc.

This work is licensed under the Creative Commons Attribution International License (CC BY).

http://creativecommons.org/licenses/by/4.0/

(c) (i) Open Access

\section{Abstract}

The city of Agadir is one of the best tourist destinations in Morocco, considered as one of the most beautiful bay in the world, which has a port infrastructure and strong industry based on the processing of seafood which often implicated as the source of odors. In order to identify in real time the sources responsible for the odors experienced in the city center and to act quickly in conjunction with industry, the Wilaya of Souss Massa Draa Region has implemented a continuous odor monitoring and tracking system using electronic noses. The treatment of meteorological data and data sent by electronic nose enables atmospheric dispersion modeling, which allows to follow instantly the odor level in the study area and to identify the sources responsible for odors with receiving warning of incidents odors, data analysis system generated every four minutes allowed to have results confirmed by companions of questionnaires to nearby residents. To reduce odors, recommendations have been suggested, which is to set up affordable and efficient practices.

\section{Keywords}

Dispersion Modeling, Electronic Nose, Enose, Odor Monitoring System, Treatment

\section{Introduction}

In the production process of seafood (fish meal production, canning, etc.), management of odors is a major concern for both the industry required to control the nuisance and for residents expecting respect and enjoyment of

${ }^{*}$ Corresponding author. 
their neighbourhood [1] [2].

The industrial site of Anza includes four seafood manufacturers contributing largely to the odor nuisances in the tourist area; this is in addition to the port being a large source of fish supply whose contribution to the odor is significant. These sites are the source of various complaints from neighbors and more generally the whole tourist area.

With the aim to limit the impact of these odor producing sites on the neighborhood and tourist area, an odor audit was carried out. The odor audit allowed verification of odors generated from the designated sites and identification of emission sources at these sites. The results enabled the creation of a hierarchy of these sites and odor sources in terms of potential harm and nuisances. The ranking enabled an evaluation of each source and site to identify scenarios and their specific parameters (type of production, weather conditions, etc.) generating odors and resulted in data parameters of generating odor nuisances within short and long distances from the sites, as well as identifying solutions (operational and technical) that are optimal in the minimization of odors [3]. This odor audit has provided the industrial operational guidelines to reduce odors [4]. These approaches have allowed identifying suitable sites for the installation of the continuous odor tracking and monitoring system using six electronic noses and meteorological stations at six different sites.

This system allows incorporating manufacturers into the process of reducing odors and to allow their sites to be self-monitoring.

This system can also check in real time the level of air quality in terms of odor and analyse the relationship between perceived odors and emissions from industrial sites.

\section{Methods}

As part of the search for solutions to problems of frequent odors in the city of Agadir, an odor assessment on industrial units north of Agadir in Anza led to the identification, characterization and hierarchical categorization of sources of odors generated in the environment and the identification of parameters generating these nuisances. This odor analysis and impact tracking helped define the placement of a continuous system to track and monitor odors and integrate other stationary sources to assess the impact on the neighbourhood [5].

Odotech's system, OdoWatch ${ }^{\circledR}$, like his architecture is showed in Figure 1, was installed to serve as an integrated system for continuous measurement of odors, tracking in real-time, with odor alerts points to feed odor data to the operators before the odors reached these points. It includes six electronic noses and weather stations, a central server, an application of data processing, six odor monitoring computers distributed over the six sites, and AERMOD, an atmospheric dispersion software [6] [7].

Merging meteorological data received from weather stations with those sent by electronic noses, the system

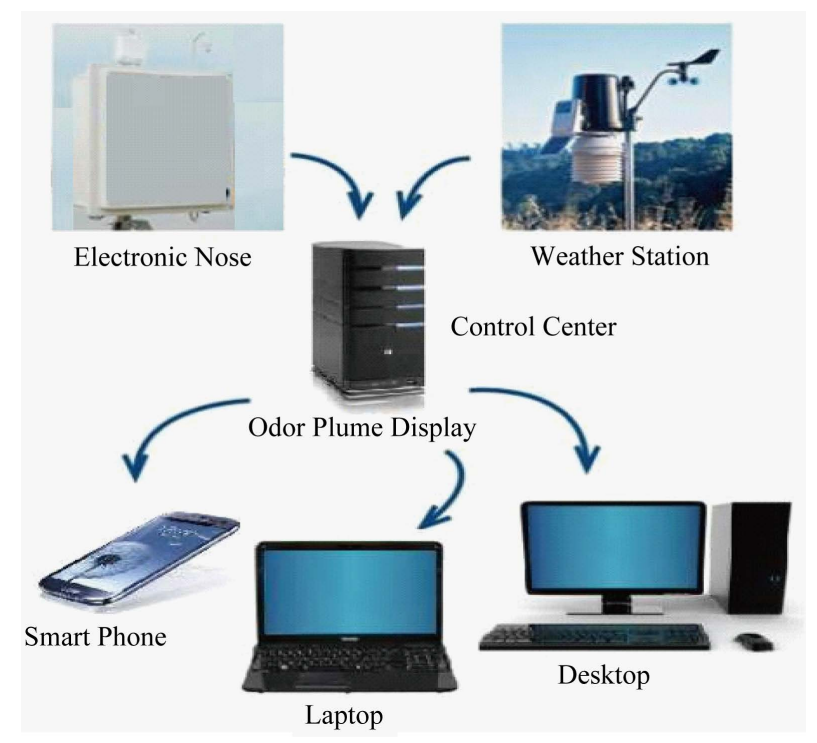

Figure 1. The architecture of continuous monitoring system of odors installed. 
models the atmospheric dispersion of odors and displays the odor plume in real time, this system is a tool that has helped inform the Industrial facilities and tailor their processes in order to reduce odors through self-monitoring, it allows them to receive alerts when there is a high probability of generating odors and identify the ones responsible for the odor complaints with proven and real time air quality verification [8].

\subsection{Description of the Sites}

In this project, six sites were identified as being likely to generate odors. In the Industrial Zone (IZ) of Anza, there are five sites ( 1 to 5 ) like showed in Figure 2. The sixth site is the port of Agadir, south of the IZ:

Sites 1, 2 and 3, produce fish meal from fresh fish and fish scraps (guano) mainly from canneries, they store raw materials outdoors, for sites 1 and 2, the output is prohibited during the day and production usually begins in the evening as of $9 \mathrm{pm}$.

The fishing port of Agadir, a source of odor emissions, is potentially generating odors comparable to the smell of fishmeal plants, this fishing port has many outdoor areas for storage of fresh fish and an area specifically for loading and unloading of fish factories producing fish meal, on occasion there are large quantities of fish dumped directly on the ground (covering an area of over $200 \mathrm{~m}^{2}$ ). The site 4 refines edible oil (soybean, sunflower, and olive), roasts coffee and distributes tea. On this site, the only potential source is the gas chimney emissions from the roaster. The site 5 is a cement plant that is closing and transferring activities to another region.

\subsection{Setting up the Monitoring System and Follow-Up Procedure}

An odor impact study was conducted to quantify the exposure of the population to odors emitted by operations on the identified sites by the following steps [9]:

- The first step was to characterize the odor emissions sources present on the sites. Odorous effluents were collected and analyzed by an olfactometer according to European standard EN 13725.

- The second step is to estimate the impact of these emissions on the neighborhood with a modeling of atmospheric odor dispersion. This step requires various data and information including a site survey, identification of odor sources, the configuration of the sources, the choice of an atmospheric dispersion model, the local meteorological data and topographical data [10].

\subsection{Region of Study}

Agadir city is the capital in the Souss Massa Draa Region. The city has about 350,000 inhabitants, it is the main Moroccan beach resort and welcomes more than 750,000 visitors every year.

The area of the study is a $15 \mathrm{~km}$ by $15 \mathrm{~km}$ zone that touches the main neighborhoods surrounding the industrial zone of Anza (IZ), Figure 3 shows the study area including the areas of emissions (the port of Agadir and the industrial Anza (IZ)) and impact areas (tourist area and Agadir city center).

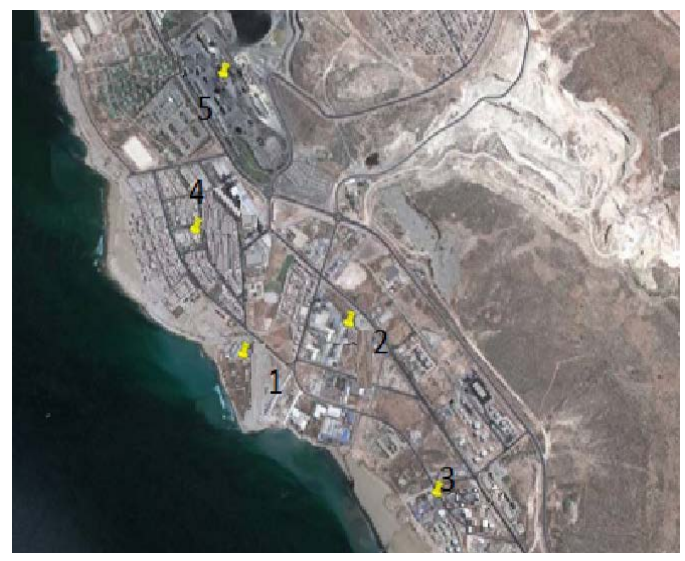

Figure 2. Implantation sites in the industrial zone of Anza (IZ). 


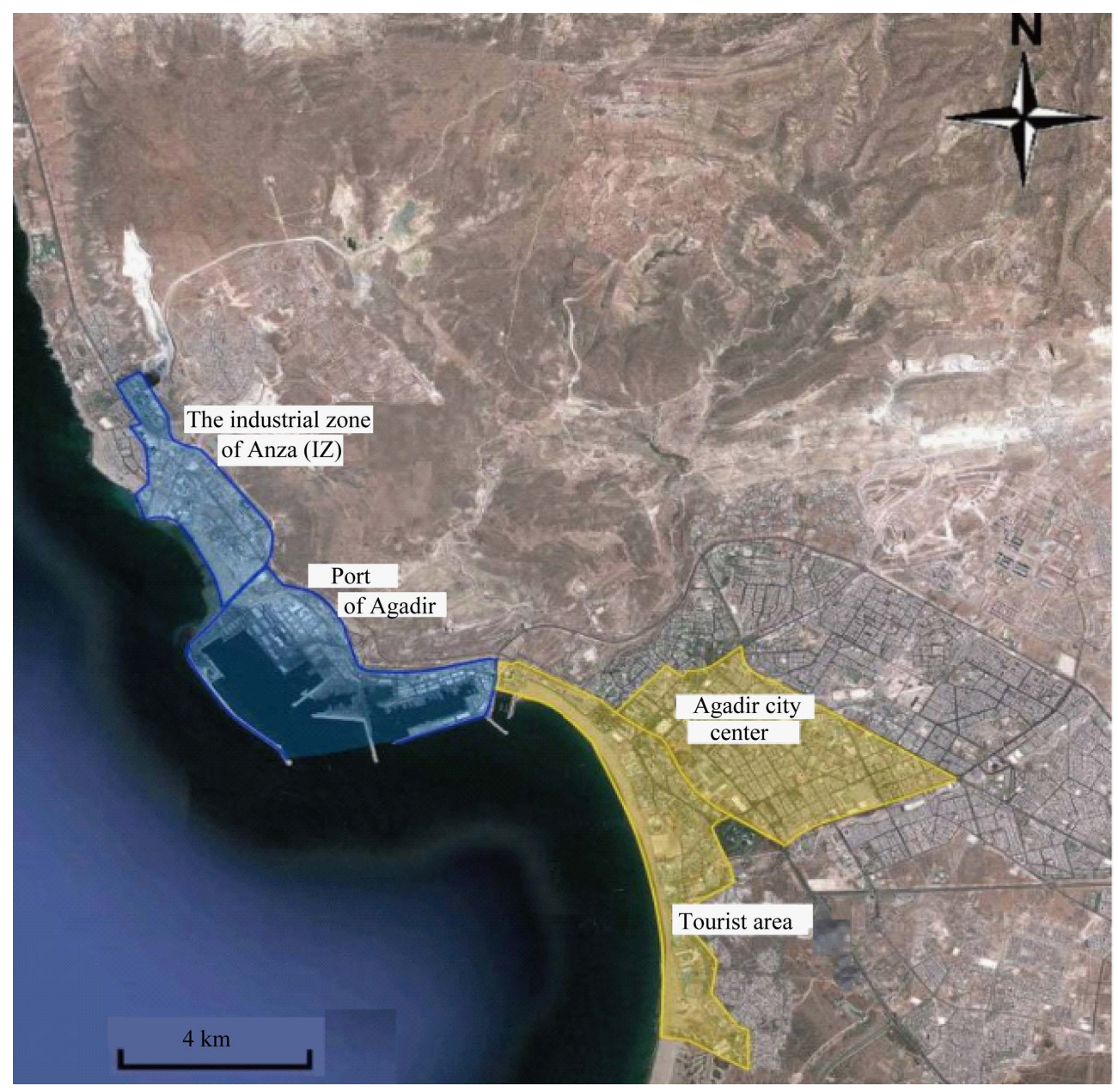

Figure 3. Region of study.

\subsection{Meteorology}

Prevailing winds are mainly from the west, west-south-west and east, based on the direction of the wind, it has been determined that they are very unlikely to cause odor transport from the IZ to the tourist area and the city center. However, the presence of the cornice is likely to create a preferential passage to the tourist area and the city center by winds coming from the west-south-west to south.

\section{Results and Discussion}

Odor samples were collected from each source mentioned above according to standard EN 13725 for olfactometry analysis [11] [12].

\subsection{Odor Impact Study from the Entire Site (Scenario 1)}

This scenario corresponds to the use of fresh fish on site, Table 1 shows the contribution rate and the odors coming from each site.

The sites present very high emission rates, which is largely due to the lack of a system for the treatment of gaseous effluents, except for Sites 3 and 5. According to the results presented, the odor emissions from Site 2 are particularly high compared to other sites. However, had Site 1 used fish more than 24 hours old, it would have brought the contribution of that site to more than $60 \%$ of total emissions, globally it can be seen that the plants producing fish meal are mainly responsible for the odor emissions (over $85.9 \%$ ), however, it is necessary to clarify that there is no direct relationship between the emission rates and the impact generated by the odors [13] 
Table 1. Odor emission from study sites.

\begin{tabular}{ccc}
\hline Sites & Contribution & Odor Emissions [o.u.E/s] \\
\hline Site 2 & $44.9 \%$ & 439,286 \\
Site 3 & $25.3 \%$ & 247,352 \\
Site 1 & $15.7 \%$ & 153,837 \\
Site 5 & $10.8 \%$ & 105,414 \\
Port of Agadir & $1.9 \%$ & 18,360 \\
Site 4 & $1.3 \%$ & 13,071 \\
& Total & 977,320 \\
\hline
\end{tabular}

[14]. In reality, the physical characteristics of each site and their sources (height and flow rate), the meteorological conditions, all have an important influence on the odor nuisances generated [15].

Following the odor emission characterization of the different sites and the effect of storage time of the fish before its use in the manufacturing of fish meal, it was observed at Site 1 that there was a variance of $1000 \%$ between Scenarios 1 and 2, Table 2 shows Odor Emission from both scenarios.

The maximum hourly odor concentration is 272 o.u.E $/ \mathrm{m}^{3}$ in the industrial zone like showed in Figure 4, it should be noted that the maximum odor concentrations are generally recorded during the night with low wind speeds of less than $1.5 \mathrm{~m} / \mathrm{s}$ and the Agadir marina is exposed to odor concentration higher than $14 \mathrm{o.u} \cdot \mathrm{E} / \mathrm{m}^{3}, 2 \%$ of the time. It is to be noted that at the sensitive receptors, the perception threshold $\left(0 . \mathrm{u}_{\mathrm{E}} / \mathrm{m}^{3}\right)$ is exceeded between $28.4 \%$ (103 days/year) and $0.2 \%$ (17.5 hours/year). For the 5 o.u.E $/ \mathrm{m}^{3}$ threshold, frequencies are exceeded between $7.4 \%$ (27 days/year) and $0.1 \%$ (8.7 hours/year).

\subsection{Odor Impact Study from the Entire Site (Scenario 2)}

This scenario (with use of fish stored for more than 24 hours on Site 1) occurs less frequently than that presented in the previous section. In the industrial area, the maximum odor concentration is very high with a maximum of 4519 o.u.E $/ \mathrm{m}^{3}$ like showed in Figure 5, more than 15 times the calculated values in Scenario I, at receptor located west of Anza's IZ at a distance of $120 \mathrm{~m}$, the maximum concentration estimated is 585 o.u.E $/ \mathrm{m}^{3}$. These high concentrations correspond to the impact from the use of fish stored longer than 48 hours on Site 1.

In Scenario 2, odor emissions from the Site 1 are 10 times greater than in Scenario 1. Consequently, the contribution of these emissions come mainly from receptors north of the IZ and in the tourist area. However, the residential area located in the Agadir marina and the cornice is heavily influenced by the port of Agadir given their proximity.

The installation of the real-time odor tracking and monitoring system that integrated all odor sources identified in the odor impact study enriches the strategy to reduce odor nuisances by measuring odors at the sources. Using this system allows the establishment of a real policy of minimizing odors by operators through the intelligent use of certain processing solutions and by providing a tool that verifies and measures the odors generated at the site(s).

This odor monitoring system displays the odor plumes generated by industrial sites every 4 minutes. It is married to a weather station to take into account the local meteorological conditions. This allows the operator to see the odor dispersion and reflects the odor levels that will perceived by residents (Figure 6).

Zooming in on the alert points (representing sensitive receptors), the odor peaks as well as the sources that are causing the odor can be identified (Figure 7).

The continuous odor monitoring system showed that the odors at the alert points vary depending on the location like showed in Table 3, in fact, emissions from Sites 1, 2, 3 and 4 respectively contribute $98 \%$ and $41 \%$ to the average concentration of odors in residential neighborhoods located west and east of the district ZI. Eastern $\mathrm{ZI}$ is influenced by emissions from Site 5 , given the proximity of the site.

By contrast, in the tourist area, close to the sea, the port of Agadir has a significant contribution to the odor impact ranging from $96 \%$ at the Agadir Marina to $43 \%$ at Sofitel hotel. Thus, we find that the sites responsible for odor nuisances, during normal production mode, are first the port of Agadir, second the Site 1 (especially in the tourist area) and then Site 3, especially in the city center. 
Table 2. Odor Emission from both scenarios.

\begin{tabular}{|c|c|c|c|}
\hline \multirow{2}{*}{ Scenario 1} & Odor Emission & \multirow{2}{*}{ Scenario 2} & Odor Emission \\
\hline & [o.u.E.E $/$ s] & & [o.u.e. $/ \mathrm{s}]$ \\
\hline Site 1 (Fresh Fish) & 153,837 & Site 1 (Fresh Fish +48 h) & $1,534,625$ \\
\hline Site 2 & 439,286 & Site 2 & 436,149 \\
\hline Site 3 & 247,352 & Site 3 & 247,352 \\
\hline Site 4 & 13,071 & Site 4 & 13,071 \\
\hline Site 5 & 105,414 & Site 5 & 105,414 \\
\hline The Port & 18,360 & The Port & 18,360 \\
\hline Total & 977,320 & Total & $2,954,971$ \\
\hline
\end{tabular}

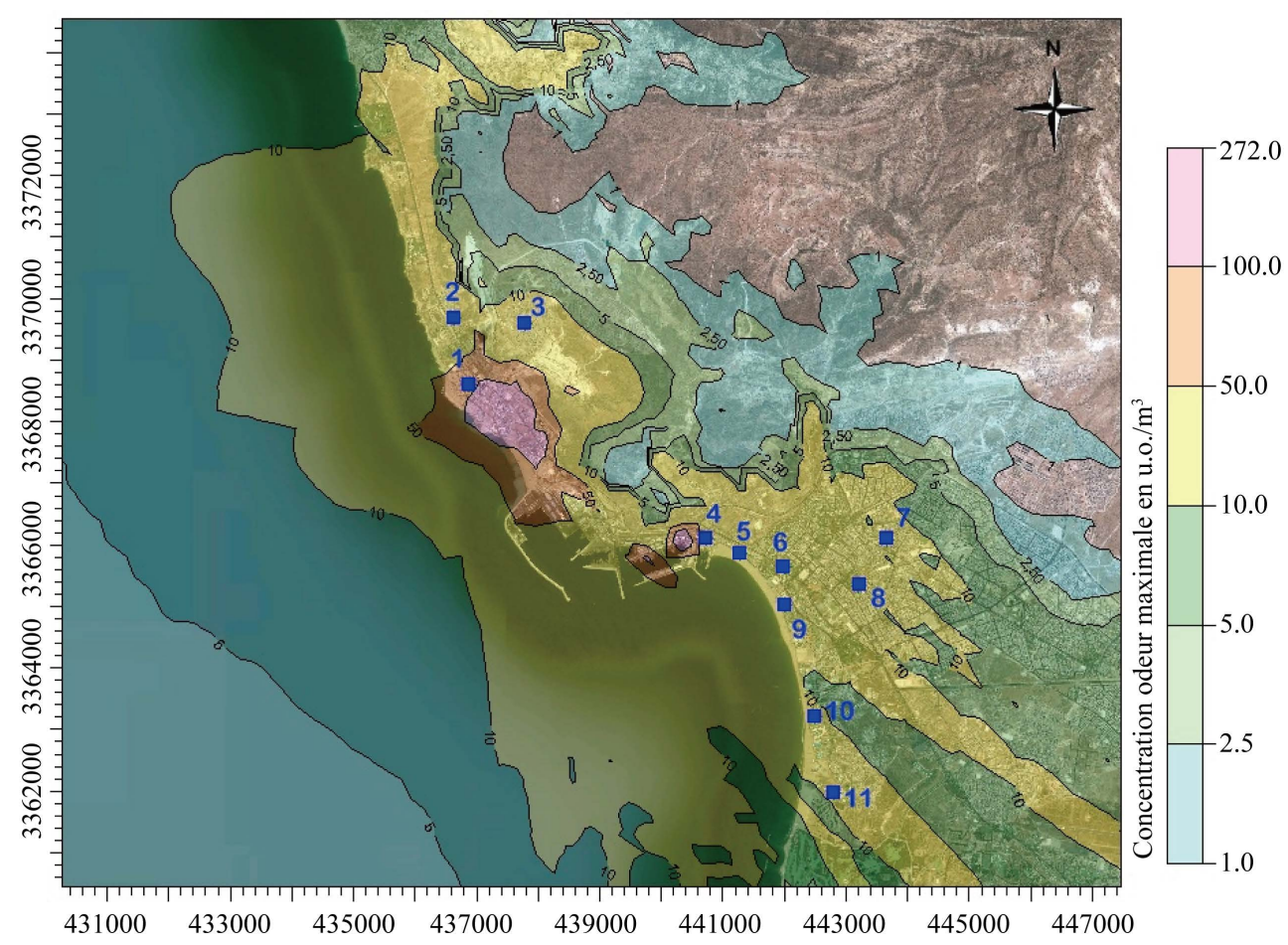

Figure 4. Maximum hourly odor concentration-Scenario 1.

In addition to the odor emission rates at the sites, weather conditions have a significant impact on odor nuisance generated. It was found that the highest concentrations of odor occur when the winds are very low, less than $2.6 \mathrm{~m} / \mathrm{s}$ [16]. At all sites, odor emissions are higher in the evening and at night than during the day as production Sites 1 and 2 only work at night.

A field monitoring campaign carried out from early April to late June 2012 by a team of odor observers in the tourist area, was done in order to obtain an accurate and quantitative understanding of all perceptible odors in these neighbourhoods, the results of this campaign were analyzed from a location point of view, the odor intensity and number of odor episodes associated fish processing plant at the port [17].

The frequencies of observations by the team of barely perceptible odors, perceptible odors and very noticeable odor corroborated the results of the odor monitoring system.

In order to reduce the odor several solutions should be considered. The objective of reducing the odor emissions for each site by $80 \%$ is perfectly attainable. This reduction in emissions would reduce odor to the city center and the tourist area to a level below the odor perception threshold. 


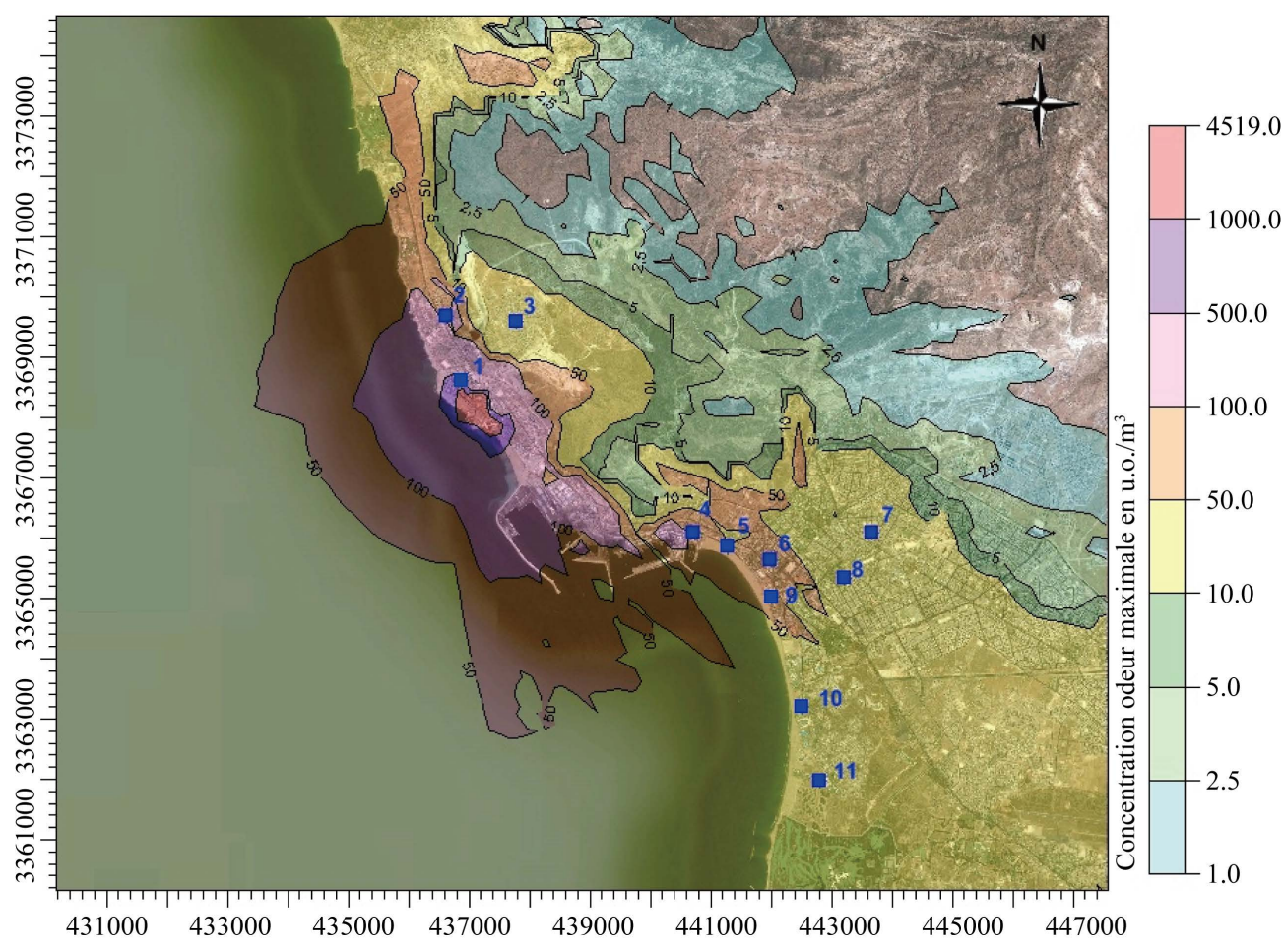

Figure 5. Maximum odor concentration-Scenario 2.

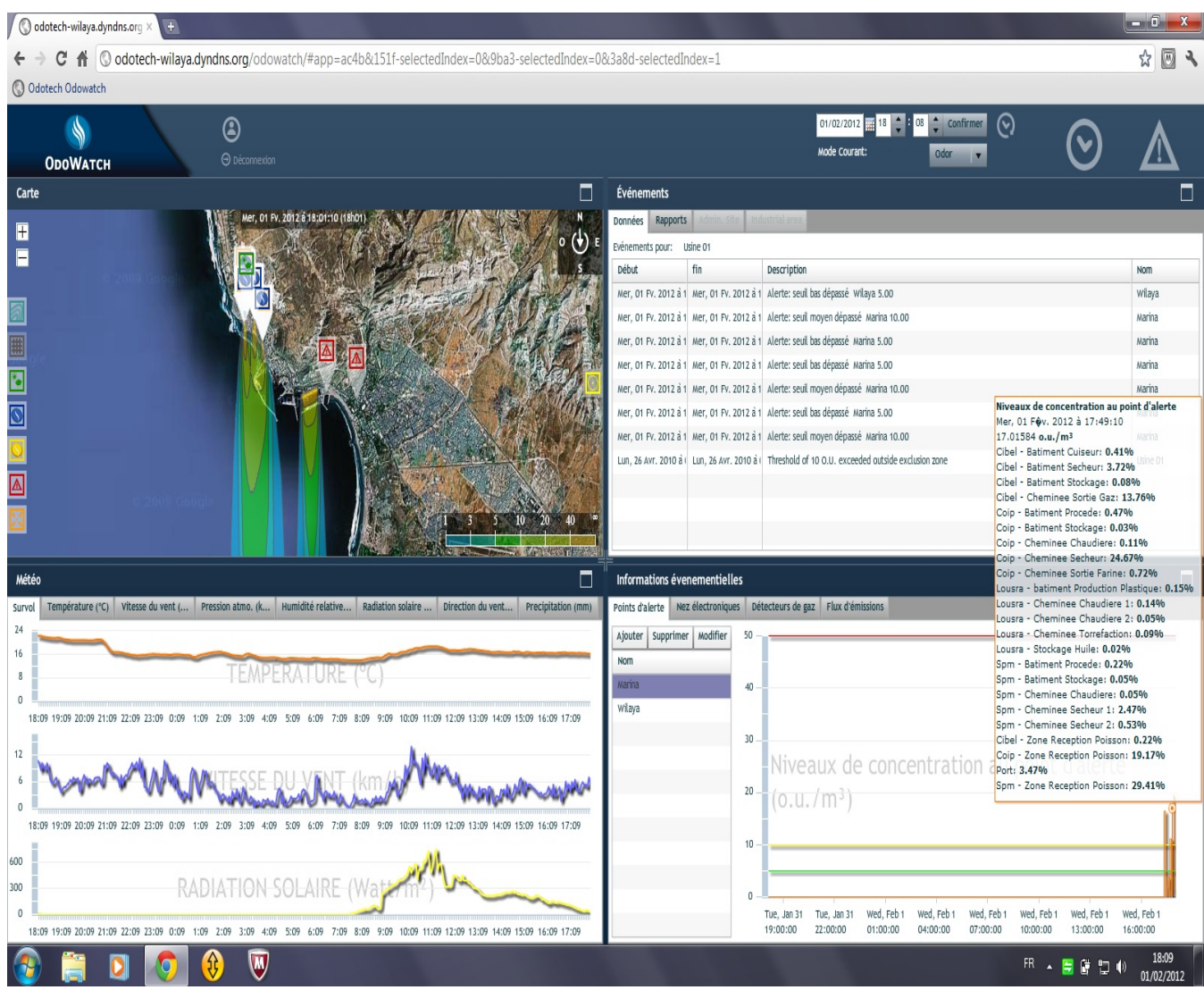

Figure 6. Odor monitoring user interface. 


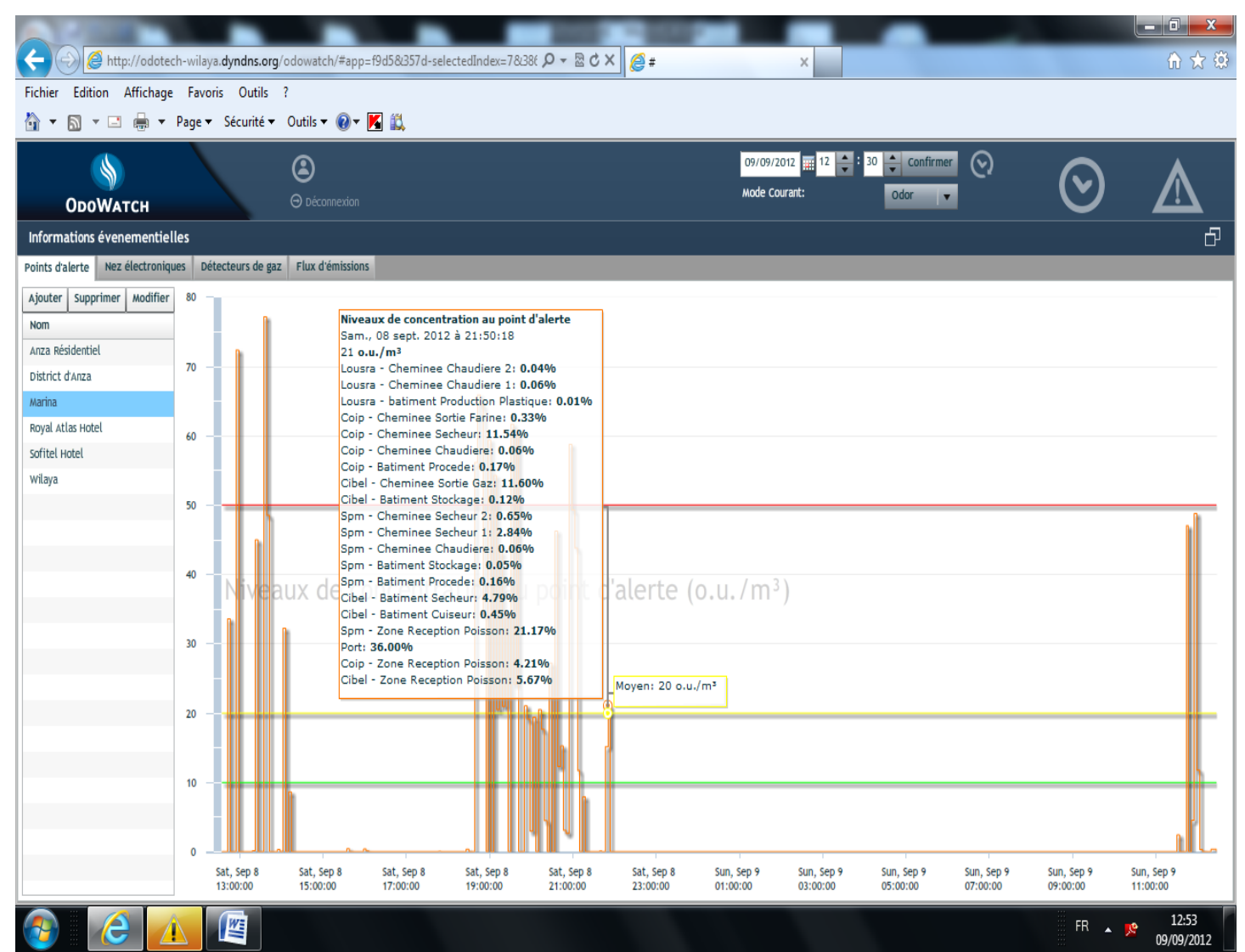

Figure 7. Odowatch web interface zoomed in on the alert points.

Table 3. Average contribution of each facility to the odor concentration calculated at alert points.

\begin{tabular}{lccccccc}
\hline Alert Points & $\begin{array}{c}\text { Max } \\
\text { o.u.E } / \mathrm{m}^{3}\end{array}$ & $\begin{array}{c}\text { Site } 1 \\
\%\end{array}$ & $\begin{array}{c}\text { Site 2 } \\
\%\end{array}$ & $\begin{array}{c}\text { Site 3 } \\
\%\end{array}$ & $\begin{array}{c}\text { Site 4 } \\
\%\end{array}$ & $\begin{array}{c}\text { Site 5 } \\
\%\end{array}$ & $\begin{array}{c}\text { Port of } \\
\text { Agadir \% }\end{array}$ \\
\hline Residential Zone-West of ZI & 69 & 30 & 37 & 9 & 22 & 0 & 2 \\
Residential Zone-East of ZI & 12 & 16 & 24 & 0 & 1 & 59 & 0 \\
Agadir Marina & 12 & 1 & 2 & 1 & 0 & 0 & 96 \\
The Wilaya (Prefecture) & 15 & 14 & 22 & 22 & 2 & 0 & 40 \\
Royal Atlas Hotel & 4 & 11 & 15 & 11 & 1 & 0 & 62 \\
Sofitel Hotel & 3 & 18 & 26 & 11 & 2 & 0 & 43 \\
\hline
\end{tabular}

The areas to consider solutions which can bring about a reduction in odor are twofold; at first business process and operations, in the second introduction of new technology [18].

At the business process and operations level:

- Optimization of production periods: favorable weather conditions favor the dispersion of odors (winds over $10 \mathrm{~km} / \mathrm{h}$ and direction NNE to SSW).

- Minimize outside storage time of the fish from 48 hours to 10 hours.

- Optimization of flow rates and temperatures of chimneys: minimize the flow of exhaust gases and operating temperature (no optimization is currently in place and this is a factor in maximizing nuisances).

At the technological level:

- Cover the surface sources

- Gas scrubbing: treating outlet gas by washing with sea water

- Neutralizers: use odor neutralizers, especially for large odor sources. 


\section{Conclusion}

After reviewing the characteristics of each of odor source and the sites described above including the objective of reducing odor emissions by $80 \%$, we can conclude that the ongoing use of the continuous odor tracking and monitoring system has achieved the objective and contributes to the growth tourism in the city of Agadir Morocco and its reputation as a leader in air quality leading to a quality of life for its residents and visitors.

\section{Acknowledgements}

The authors would like to greatly thank the Wali of the Souss Massa Draa Region.

\section{References}

[1] Mao, F., Chen, M.-R., Wang, L., Chen, M.-L., Lai, S.-C. and Tsai, C.-J. (2012) Method Development for Determining the Malodor Source and Pollution in Industrial Park. Science of the Total Environment, 437, 270-275. http://dx.doi.org/10.1016/j.scitotenv.2012.08.056

[2] Gyu Seo, S., Kun Ma, Z., Min Jeon, J., Chul Jung, S. and Bum Lee, W. (2011) Measurements of Key Offensive Odorants in a Fishery Industrial Complex in Korea. Atmospheric Environment, 45, 2929-2936. http://dx.doi.org/10.1016/j.atmosenv.2011.01.032

[3] Odotech (2001) Caractérisation des émissions atmosphériques et évaluation de l'impact-odeur du lieu d'enfouissement sanitaire de la régie intermunicipale Argenteuil Deux Montagnes (Atmospheric emissions characterization and odor impact assessment of Argenteuil Deux Montagnes landfill area). Odotech Inc., Montréal.

[4] Nicolas, J., Cors, M., Romain, A.-C. and Delva, J. (2010) Identification of Odour Sources in an Industrial Park from Resident Diaries Statistics. Atmospheric Environment, 44, 1623-1631. http://dx.doi.org/10.1016/j.atmosenv.2010.01.046

[5] Snidar, R., Culòs, B., Trovarelli, A., Soldati, A., Sironi, S. and Capelli, L. (2008) Evaluation of Odour Emissions from a Landfill through Dynamic Olfactometry, Dispersion Modelling and Electronic Noses. Chemical Engineering Transactions, 15, 315-322.

[6] EPA (2004) AERMOD: Description of Model Formulation. US Environmental Protection Agency, Research Triangle Park.

[7] Capelli, L., Sironi, S., Del Rosso, R., Céntola, P. and Grande, M.I. (2008) A Comparative and Critical Evaluation of Odour Assessment Methods on a Landfill Site. Atmospheric Environment, 42, 7050-7058.

[8] Micone, P.G. and Guy, C. (2007) Odour Quantification by a Sensor Array: An Application to Landfill Gas Odours from Two Different Municipal Waste Treatment Works. Sensors and Actuators B, 120, 628-637. http://dx.doi.org/10.1016/j.snb.2006.03.026

[9] Gorgy, T.G.A. (2003) Validation of an Air Dispersion Model for Odour Impact Assessment. McGill Unversity, Montreal.

[10] Guo, H., Jacobson, L.D., Schmidt, D.R. and Janni, K.A. (2001) Simulation of Odor Dispersion as Impacted by Weather Conditions. ASAE Publication Number 701P0201, St. Joseph.

[11] ASTM (2004) ASTM E679-04: Standard Practice for Determination of Odor and Taste Thresholds by a Forced-Choice Ascending Concentration Series Method of Limits. American Society for Testing and Materials, Philadelphia.

[12] EN 13725 (2003) Air Quality-Determination of Odour Concentration by Dynamic Olfactometry. Comité Européen de Normalisation, Brussels, April 2003, 1-70. http://www.cenorm.be

[13] Sironi, S., Capelli, L., Cèntola, P., Del Rosso, R. and Pierucci, S. (2010) Odour Impact Assessment by Means of Dynamic Olfactometry, Dispersion Modelling and Social Participation. Atmospheric Environment, 44, 354-360. http://dx.doi.org/10.1016/j.atmosenv.2009.10.029

[14] Zhang, Q., Feddes, J.J.R., Edeogu, I.K. and Zhou, X.J. (2003) Correlation between Odor Intensity Assessed by Human Assessors and Odor Concentration Measured with Olfactometers. Canadian Biosystems Engineering, 44, $27-32$.

[15] Capelli, L., Sironi, S., Del Rosso, R., Céntola, P., Rossi, A. and Austeri, C. (2011) Odour Impact Assessment in Urban Areas: Case Study of the City of Terni. Procedia Environmental Sciences, 4, 151-157. http://dx.doi.org/10.1016/j.proenv.2011.03.018

[16] Ratto, G., Videla, F., Maronna, R., Flores, A. and De Pablo, F. (2010) Air Pollutant Transport Analysis Based on Hourly Winds in the City of La Plata and Surroundings, Argentina. Water Air and Soil Pollution, 208, 243-257. http://dx.doi.org/10.1007/s11270-009-0163-0

[17] Romain, A.C., Delva, J. and Nicolas, J. (2008) Complementary Approaches to Measure Environmental Odours Emitted 
by Landfill Areas. Sensors and Actuators B, 131, 18-23. http://dx.doi.org/10.1016/j.snb.2007.12.005

[18] Solan, P.J., Dodd, V.A. and Curran, T.P. (2010) Evaluation of the Odour Reduction Potential of Alternative Cover Materials at a Commercial Landfill. Bioresource Technology, 101, 1115-1119.

http://dx.doi.org/10.1016/j.biortech.2009.09.030 
Scientific Research Publishing (SCIRP) is one of the largest Open Access journal publishers. It is currently publishing more than 200 open access, online, peer-reviewed journals covering a wide range of academic disciplines. SCIRP serves the worldwide academic communities and contributes to the progress and application of science with its publication.

Other selected journals from SCIRP are listed as below. Submit your manuscript to us via either submit@scirp.org or Online Submission Portal.
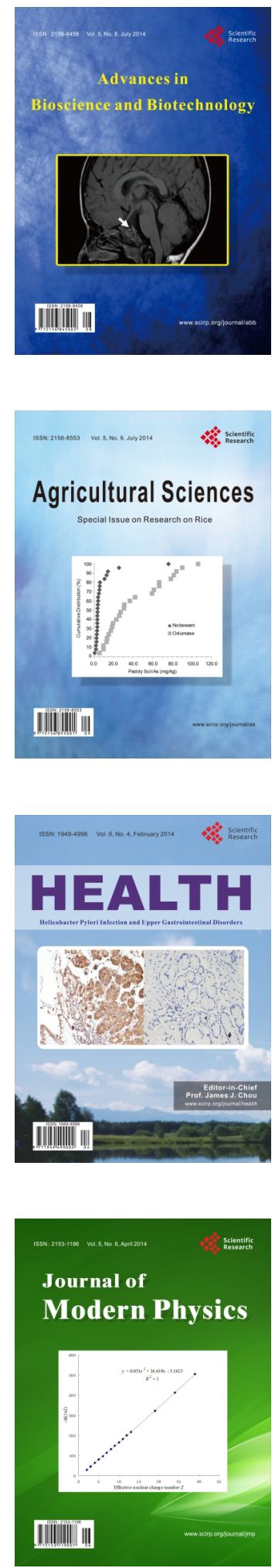
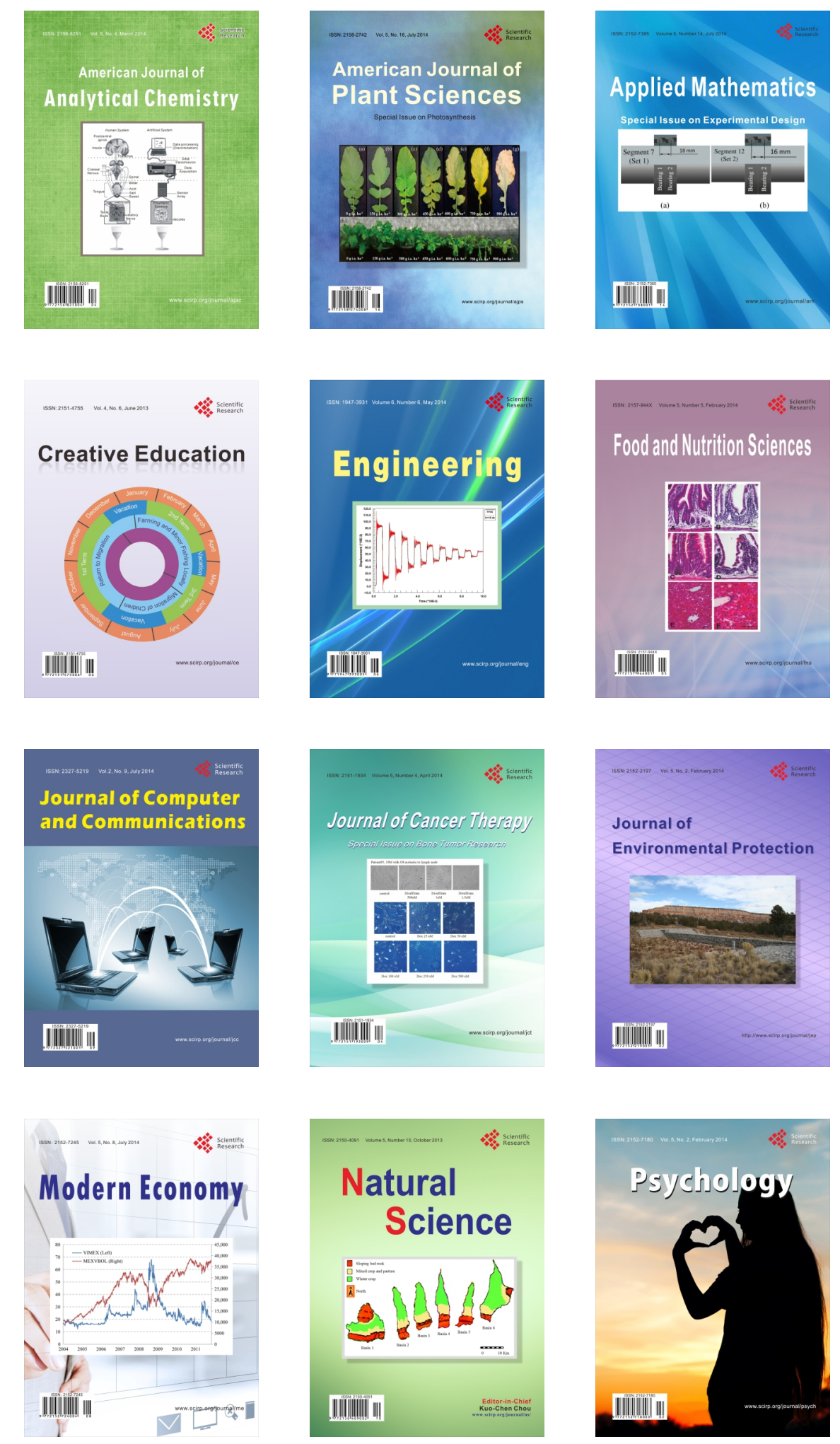